\title{
Control of distal antennal identity and tarsal development in D rosophila by spineless-aristapedia, a homolog of the mammalian dioxin receptor
}

\author{
Dianne M. Duncan, Elizabeth A. Burgess, and Ian Duncan ${ }^{1}$ \\ Department of Biology, Washington University, St. Louis, Missouri 63130 USA
}

\begin{abstract}
We report the molecular characterization of the spineless (ss) gene of D rosophila, and present evidence that it plays a central role in defining the distal regions of both the antenna and leg. ss encodes the closest known homolog of the mammalian dioxin receptor, a transcription factor of the bHLH-PAS family. Loss-of-function alleles of ss cause three major phenotypes: transformation of distal antenna to leg deletion of distal leg (tarsal) structures, and reduction in size of most bristles. Consistent with these phenotypes, ss is expressed in the distal portion of the antennal imaginal disc, the tarsal region of each leg disc, and in bristle precursor cells. Ectopic expression of ss causes transformation of the maxillary palp and distal leg to distal antenna, and induces formation of an ectopic antenna in the rostral membrane. These effects indicate that ss plays a primary role in specifying distal antennal identity. In the tarsus, ss is expressed only early, and is required for later expression of the tarsal gene bric à brac (bab). Ectopic expression causes the deletion of medial leg structures, suggesting that ss plays an instructive role in the establishment of the tarsal primordium. In both the antenna and leg, ss expression is shown to depend on D istal-less (DII), a master regulator of ventral appendage formation. The antennal transformation and tarsal deletions caused by ss loss-of-function mutations are probably atavistic, suggesting that ss played a central role in the evolution of distal structures in arthropod limbs.
\end{abstract}

[Key Words: Homeotic gene; dioxin receptor; aryl hydrocarbon receptor; PAS domain; antennal specification; leg development; spinel ess-aristapedia]

Received N ovember 20, 1997; revised version accepted M arch 2, 1998.

The identities of body segments in the trunk and posterior head of Drosophila are controlled by the homeotic genes of the Antennapedia (ANT-C) and bithorax (BX-C) complexes (for reviews, see Lewis 1978; Duncan 1987; Kaufman et al. 1990). Although the ANT-C and BX-C genes specify most aspects of body segment specialization, at least three appendage structures develop independently of these genes. First, Carroll et al. (1995) have shown that wing formation in the second thoracic segment (T2) requires no input from the ANT-C and BX-C genes. Instead, these genes function to repress wing development in all segments but T2. Second, the antenna receives no input from the ANT-C and BX-C genes, as these are not expressed within the antennal segment (Kaufman et al. 1990; Jürgens and Hartenstein 1993). Third, formation of the distal part (the tarsus) of the T2 leg appears not to require ANT-C or BX-C genes, as normal second leg tarsi are produced by clones homozygous for null alleles of Scr, Antp, or U bx (Struhl 1981, 1982b;

${ }^{1}$ Corresponding author.

E-MAIL duncan@biodec.wustl.edu; FAX 314 935-5125.
Abbott and Kaufman 1986), the ANT-C and BX-C genes that specify segment identities in the thorax. These genes do, however, play an important role in more proximal regions of the second leg, and in both proximal and distal regions of the first and third legs (Struhl 1982b).

What genes are responsible for specifying devel opment of the wing, antenna, and T2 tarsus? For the wing, a key gene appears to be vestigial (vg). vg encodes a novel nuclear protein that is expressed in the pouch region of the wing imaginal disc (Williams et al. 1991). Ectopic expression of vg causes the development of wing tissue in other discs, indicating that $\mathrm{vg}$ is a primary determinant of wing development (Kim et al. 1996). However, no genes have been identified that play similar roles for the antenna or T2 tarsus. In this report, we present evidence that the spinel ess (ss) gene plays a key role in specifying the devel opment of both structures. Loss-of-function alleles of ss cause transformation of the distal part of the antenna (arista) to distal second leg, and deletion of most of the tarsal region of each of the legs (Lindsley and Zimm 1992). In addition, these alleles cause a severe reduction in size of most bristles. Almost all ss alleles 
cause the antennal homeotic transformation, and are known as spineless-aristapedia $\left(\mathrm{ss}^{\mathrm{a}}\right)$ al leles. M ost allel es affect bristle size to some degree, but only very strong alleles also cause tarsal deletions (Struhl 1982a). Although ss has been known for many years, there has been little interest in the gene because its pl ei otropy has been taken to suggest that it plays some general, perhaps metabolic, role (see, e.g., Raff and Kaufman 1983).

In this report we describe the molecular characterization of ss. The results are not consistent with a general metabolic function. We find that ss encodes the closest known homolog of the mammalian dioxin receptor, a bHLH-PAS domain transcription factor. ss is not expressed uniformly, but shows distinct expression patterns that correspond to its three major functions. ss transcripts accumulate in the distal portion of the antennal disc, in the tarsal regions of the leg discs, and in bristle precursor cells. ss is al so expressed in the embryo in the antennal segment, the thoracic imaginal primordia, and the peripheral nervous system. Ectopic expression of ss causes transformation of the maxillary palp and distal leg to distal antenna, and induces development of an ectopic antenna in the rostral membrane, which normally has no appendage. These effects argue that ss is a primary determinant of antennal identity. In the tarsus, ss is expressed only early in development and is required for later expression of the tarsal gene bric à brac (bab) (Godt et al. 1993). This suggests that ss functions in the establishment of the tarsal primordium. Ectopic expression of ss causes the del etion of medial leg structures, perhaps because these are incorrectly specified as tarsus. ss expression in both the antenna and leg is shown to be dependent upon Distal-less (DII), a master regulator of ventral appendage development (Cohen and Jürgens 1989; Gorfinkiel et al. 1997). We argue that ss has played an important role in the evolution of both the antenna and the distal leg.

\section{Results}

\section{Cloning of the ss gene}

The ss locus was tagged by a P-element insertion. The insertion allele, now lost, caused a weak ss ${ }^{\mathrm{a}}$ phenotype when homozygous, carried a P-element at the ss locus (polytene bands 89C 1,2; Lewis 1963), and was revertable to $\mathrm{Ss}^{+}$by mobilization of the $\mathrm{P}$ element. Following isolation of P-element containing clones from the locus, phage clones covering $\sim 30 \mathrm{~kb}$ to either side of the $\mathrm{P}$ element insertion were recovered by chromosome walking. A map of the cloned DN A is presented in Figure $1 \mathrm{~A}$.

To clarify the genetic organization of ss, a screen for new X-ray-induced alleles was conducted. The 25 mutants recovered are summarized in Table 1 . Eleven of these, as well as six pre-existing rearrangements, were

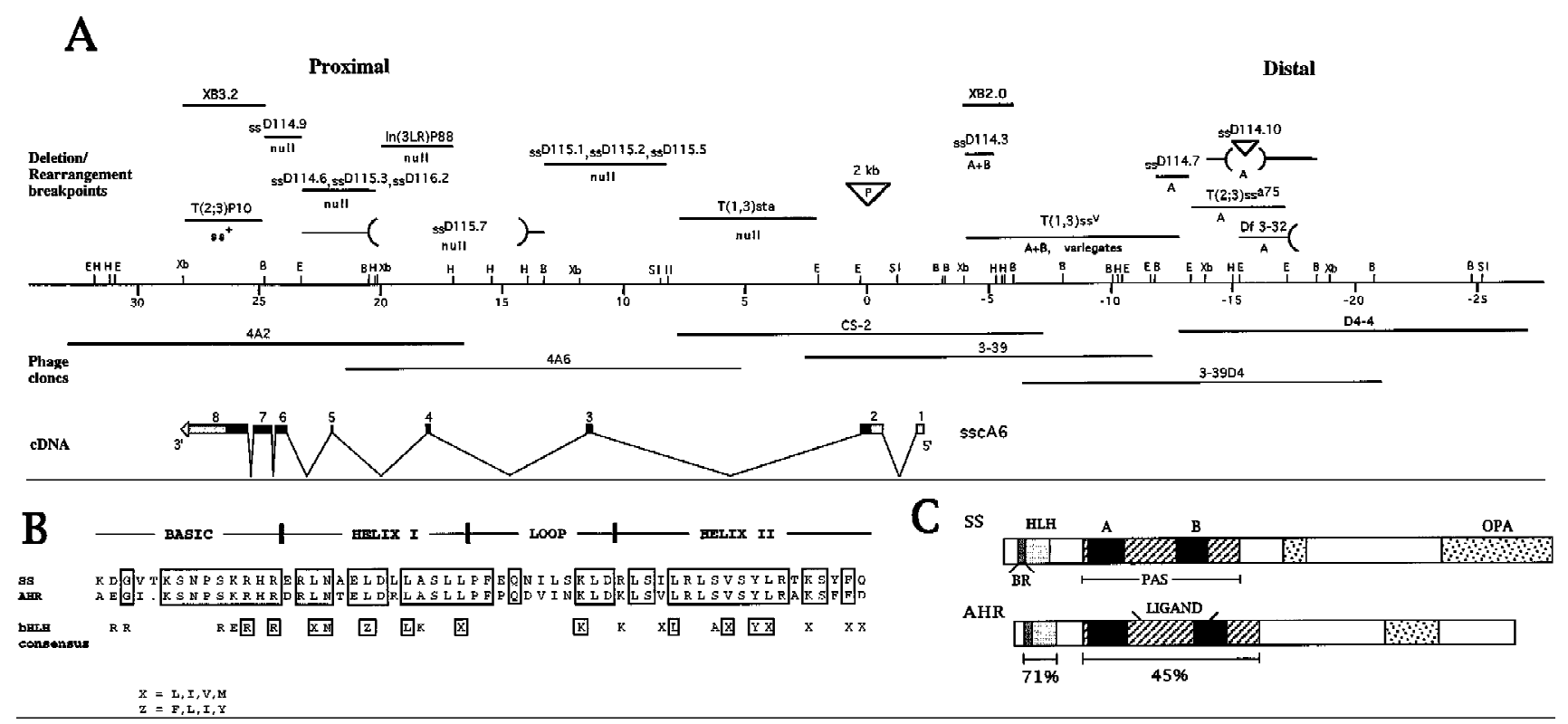

Figure 1. Molecular analysis of the ss locus. (A) M ap of the cloned DNA. Coordinates are in kb; position 0 is the insertion site of the P-element tag used to clone the locus. (B) BamHI; (E) EcoRI; (H) HindlII; (SI) Sal I; (Xb) Xbal. Overlapping phage clones are indicated below the restriction map; phage 3-39 is the P-element containing clone that initiated the walk. The positions of 17 breakpoint mutants are noted above the map; breakpoints and their uncertainties are indicated by lines, del etions by parentheses, and insertions by inverted triangles. The phenotypes of these mutants are noted as null, antennal transformations (A) or antennal transformations coupled with bristle defects (A+B). XB3.2 and XB2.0 indicate genomic fragments that detect transcripts when used to probe N orthern blots. Coding sequences and untranslated regions within the exons of the sscA 6 cDNA are indicated by black and shaded boxes, respectively. (B) Amino acid identity of SS to AHR in the bHLH domain. Boxed amino acids are identical between the two proteins, and identities of both sS and AHR to the bHLH consensus is noted below. (C) Structure of the ss and AHR proteins drawn to scale. $M$ otifs are noted on the ss protein schematic. (BR) Basic region; (HLH) helix-loop-helix; (A, B, PAS) A and B repeats of the PAS domain; (OPA) region of opa or CAX repeats. The position of the ligand binding domain of AHR is also noted. 
localized by Southern blotting and in situ hybridization to mutant polytene chromosomes. A proximal limit to the locus at +25 to $+28 \mathrm{~kb}$ ( 0 being the site of P-element insertion) is provided by the breakpoint of $\mathrm{Tp}(3 ; 2) \mathrm{P} 10$, which does not affect ss function. All ten of the null mutations mapped are broken within the region from about +28 through +2 . As described below, these alleles all interrupt the ss transcribed region. Six of the alleles mapped lie in the upstream region from -4 to -18 . These mutants all cause strong homeotic transformation of the distal antenna (arista) to tarsus, but do not cause distal deletions in the legs or transformed antennae. Effects on bristle size vary with position; the most proximal of the mutants in the upstream group ( $\mathrm{ss}^{\mathrm{D} 114.3}$ ) causes a strong reduction in bristle size, the $T(1 ; 3) s s^{\vee}$ al lele variegates for bristle size, and the four more distal mutants in this group cause a weak reduction in bristle size. The distal limit of ss is not known.

Northern blotting revealed two transcribed regions distal to the $\mathrm{Tp}(3 ; 2) \mathrm{P} 10$ breakpoint. A probe from the more proximal of these (from +25 to $+28 \mathrm{~kb}$ ) detects a smear of RN As ranging from 0.7 to $6.5 \mathrm{~kb}$ that has several embedded bands, the largest of which is $5.4 \mathrm{~kb}$ (not shown). The second transcribed region lies more di stally, at -4 to $-6 \mathrm{~kb}$. This region hybridizes to a major transcript of $1.2 \mathrm{~kb}$ and minor transcripts of 2.2 and $3.3 \mathrm{~kb}$. These are detected from the second larval instar through adulthood (not shown).

To assess which transcripts from ss are most important functionally, genomic regions were used as probes for in situ hybridization to transcripts in imaginal discs. The proximal region of ss gave specific signal in the three regi ons expected for ss: the antenna, legs, and bristle precursor cells. This, and other evidence described below, indicates that transcripts from this region are the major functional products of ss. In contrast, the distal transcribed region gave no specific signal in imaginal discs or embryos, and CDNAs from this region do not contain appreciable ORFs (data not shown). The significance of these transcripts is unknown. They are transcribed from a probable regulatory region of ss (see below), and may therefore be similar to the bxd and iab region transcripts of the bithorax complex (Lipshitz et al. 1987; Cumberledge et al. 1990).

Isolation of SS CDNAs

To isolate cDN As for the proximal transcribed region of

Table 1. New X-ray-induced ss alleles

\begin{tabular}{|c|c|c|c|}
\hline Allele & Cytology & Hemizygous phenotype $^{a}$ & Breakpoints $^{b}$ \\
\hline SS $^{\mathrm{D} 114.1}$ & Df(3R)89A-B;89E present & - & - \\
\hline $\mathrm{SS}^{\mathrm{D} 114.2}$ & normal & null & N.D. \\
\hline $\mathrm{SS}^{\mathrm{D} 114.3}$ & $\mathrm{~T}(1 ; 3) 6 \mathrm{C} ; 89 \mathrm{C} 1-2$ & $A, B$ & $-4 /-5.5$ \\
\hline $\mathrm{SS}^{\mathrm{D} 114.4}$ & $\mathrm{Df}(3 \mathrm{R}) 89 \mathrm{~B} ; 89 \mathrm{C}$ & - & - \\
\hline $\mathrm{SS}^{\mathrm{D} 114.5}$ & $\mathrm{~T}(2,3) 55 \mathrm{C} ; 80 \mathrm{AB}$, normal at $89 \mathrm{C}$ & $\begin{array}{l}\text { moderate } A \text {, moderate } B \text {, } \\
\text { variable } L\end{array}$ & N.D. \\
\hline $\mathrm{SS}^{\mathrm{D} 114.6}$ & Tp(3;het);89C;90B & null & $+21 /+23$ \\
\hline $\mathrm{SS}^{\mathrm{D} 114.7}$ & $89 \mathrm{C} /$ heterochromatin & moderate $A$, moderate $B$ & $-12 /-13$ \\
\hline $\mathrm{SS}^{\mathrm{D} 114.8}$ & normal & null & N.D. \\
\hline $\mathrm{SS}^{\mathrm{D} 114.9}$ & In(3R)89B9-14;C1-2 & null & $+24 /+25$ \\
\hline $\mathrm{SS}^{\mathrm{D} 114.10}$ & normal & moderate $\mathrm{A}$ & $\begin{array}{l}-14 /-17 \text {, internal deletion } \\
\text { of at least } 1 \mathrm{~kb}+\text { insertion }\end{array}$ \\
\hline $\mathrm{SS}^{\mathrm{D} 114.12}$ & $\begin{array}{l}\text { Complex T(Y;3). Probable new order: } \\
\text { Y/84D-89CD/99F-90A/84D-61 } \\
\text { +Y/90A-89CD/100A-100F }\end{array}$ & A, moderate $B$ & N.D. \\
\hline $\mathrm{SS}^{\mathrm{D} 115.1}$ & $\ln (3 R) 88 C D ; 89 C 1-2$ & null & $+8 /+13.5$ \\
\hline $\mathrm{SS}^{\mathrm{D} 115.2}$ & normal & null & $+8 /+13.5$ \\
\hline $\mathrm{SS}^{\mathrm{D} 115.3}$ & normal & null & $+21 /+23$ \\
\hline $\mathrm{SS}^{\mathrm{D} 115.5}$ & $\mathrm{~T}(2 ; 3) 43 \mathrm{~A} ; 89 \mathrm{C} 1-2$ & null & $+8 /+13.5$ \\
\hline $\mathrm{SS}^{\mathrm{D} 115.6}$ & normal & null & N.D. \\
\hline$S^{D 115.7}$ & normal & null & $\begin{array}{l}\text { internal deletion; proximal break } \\
\text { at }+21 /+23 \text {, distal break at }+13 /+14\end{array}$ \\
\hline $\mathrm{SS}^{\mathrm{D} 115.8}$ & Df(3R)89B18-22;89D 3-5 & - & - \\
\hline $\mathrm{SS}^{\mathrm{D} 115.12}$ & $\begin{array}{l}\text { Tp(3;3)71A;89E;90B } \\
\quad+\text { Df(3R)89B20-22;89E }\end{array}$ & - & - \\
\hline$S^{D 116.1}$ & $\ln (3 R) 81 ; 89 C 1,2$ & null & N.D. \\
\hline $\mathrm{SS}^{\mathrm{D} 116.2}$ & $\begin{array}{l}\text { T(Y;3). N ew order: } \\
\text { Y/89C-84E/89C-100 +61-84E/Y }\end{array}$ & null & $+21 /+23$ \\
\hline $\mathrm{SS}^{\mathrm{D} 116.4}$ & normal & $A, B$ & N.D. \\
\hline $\mathrm{SS}^{\mathrm{D} 116.5}$ & normal & $A, B$ & N.D. \\
\hline$S^{\mathrm{D} 116.7}$ & normal & null & N.D. \\
\hline $\mathrm{SS}^{\mathrm{D} 116.8}$ & In(3R)81;99E. 89C normal & null & N.D. \\
\hline
\end{tabular}

aphenotype when heterozygous with $\mathrm{Df}(3 \mathrm{R}) \mathrm{ss}^{\mathrm{D} 114.4}$. (A) A ntennal transformation; (B) reduction in bristle size; (L) tarsal del etions. ${ }^{b}$ As determined by Southern blotting. Coordinates indicate altered restriction fragments. (N .D.) No changes detected. 
Ss, a genomic fragment from +25 to +28 was used to screen an eye-antennal imaginal disc library (kindly provided by Dr. G. Rubin, University of California, Berkeley). A pproximately $1.5 \times 10^{6}$ plaques were screened, and 10 distinct cDN As obtained. The largest of these, which is $5.2 \mathrm{~kb}$ in length, was chosen for sequence analysis. This CDNA, designated SsCA6, is probably near full length, as it is only 200 bp shorter than the largest band seen on Northerns. Exons in this CDN A are spread over a 30-kb genomic region that encompasses all the ss null breakpoints mapped, indicating that it represents a functional transcript of the locus.

\section{The ss protein}

Sequencing of SSCA 6 revealed a single ORF that encodes a protein of 884 amino acids (Fig. 2). This ORF has good Drosophila codon bias throughout. Although the sequence surrounding the putative initiating methionine does not match the Drosophila consensus well (Cavener 1987), homol ogy considerations (see bel ow) suggest this codon is the initiator. The $3^{\prime}$ portion of the ORF is rich in opa (CAX) repeats, which encode primarily glutamine or histidine. These repeats extend beyond the ORF for an additional 600-700 nucleotides. Curiously, the $3^{\prime}$ end of sscA 6 lies to the left of the Tp(3;2)P10 breakpoint, which is $\mathrm{Ss}^{+}$, implying either that the $3^{\prime}$ end of the ss transcribed region is dispensable, or that sequences able to substitute for the ss $3^{\prime}$ end are introduced by this rearrangement. As indicated in Figure 2, an additional cDNA of $2.8 \mathrm{~kb}$ (sscA5) was sequenced. The protein it encodes is three residues shorter than that encoded by sscA 6. This difference likely results from al ternate spl icing.

The putative ss protein shows extensive similarity to the human and murine aryl hydrocarbon receptor (AHR, also known as the di oxin receptor), as well as lower similarity to the human aryl hydrocarbon nuclear translocator, hypoxia-inducible factor 1 , and endothelial PAS-1 (Tian et al. 1997) and the Drosophila proteins singleminded (sim), period, and trachealess (trh) (for review, see Schmidt and Bradfield 1996). These proteins comprise a recently recognized family distinguished by the PAS domain, which can mediate protein-protein interactions (Huang et al . 1993). M ost members of the family also contain a bHLH domain. ss is most similar to AHR; as can be seen in Figure 1, there is $71 \%$ identity between the two proteins in the bHLH region, $45 \%$ identity in the PAS domain, and $41 \%$ identity overall. The organization of domains within the two proteins is al so closely similar. ss and AHR share almost twice as much sequence identity as either shares with their next closest relative, sim.

Sequencing of exons reveals that all five of the ss splice sites within the bHLH and PAS coding sequences are conserved in Ahr (Fig. 2). These splice sites lie within conserved codons in the two genes, and separate precisely the same nucleotide positions within these codons (Schmidt et al. 1993). Ahr has three additional splice sites in the PAS domain coding sequence that are not shared with ss. Three of the five splice junctions of ss are also shared with sim.

Transcript distributions in imaginal discs and the ss mutant phenotype

In situ hybridization of ss probes to imaginal discs reveal s distinct phases of transcript accumulation that correspond to the leg, antennal, and bristle functions of ss.

The leg In leg discs, ss staining is first seen in the late second instar in a central ring that corresponds to the presumptive tarsal region (Fig. 3E) (all references here to imaginal fate maps are from Bryant 1978). This ring is transient, and fades out by the late third instar. The ss tarsal ring likely corresponds to the tarsal structures deleted in ss ${ }^{-}$mutants, which include the distal part of the first tarsal segment and the second through fourth tarsal segments (Fig. 4E). After the tarsal ring fades out, ss becomes expressed in a patch in the anterior-proximal portion of the disc in a region that will giverise to structures of the thorax proper (Fig. 3F). ss null alleles show no defects in these structures.

The antenna ss staining in the antennal disc is first detected during the late second instar (not shown). At all times after this, intense staining is seen in an oval patch in the central (distal) portion of the antennal disc (Fig. $3 A$,B). After disc eversion, the limits of intense ss expression coincide precisely with the boundary between the second (AII) and third (AIII) antennal segments (Fig. 3D).

ss alleles broken in the upstream region of the gene have no effect on ss expression in the leg, but alter expression in the antenna to resemble that normally seen in the leg. The effects of a translocation broken at $-4 \mathrm{~kb}$ to $-5 \mathrm{~kb}\left(\mathrm{ss}^{\mathrm{D} 114.3}\right)$ are shown in Figure $3 \mathrm{C}$. ss is expressed in a transient ring in the antennal and leg discs in this mutant. This indicates that the antennal expression pattern of ss is control led by the region upstream of $-4 \mathrm{~kb}$ to $-5 \mathrm{~kb}$, whereas the tarsal pattern of expression is likely controlled by a downstream, perhaps intronic, region. Consistent with their effects on ss expression, mutants located in the upstream region cause transformation of the distal antenna to tarsus (Fig. 4B). However, only the distal part of AIII and the arista are affected. Detailed examination of one upstream mutant ( $\left(\mathrm{S}^{\mathrm{D} 114.7}\right)$ indicates that the antennal tarsus produced has second leg identity (see legend to Fig. 4), as suggested previously for the $\mathrm{ss}^{\mathrm{a}}$ allele (M orata and Lawrence 1979).

In ss null mutants, the antenna shows both transformation to leg and tarsal deletion (Fig. 4C). In this case, the entire AllI segment and arista are affected. Strikingly, the Alll segment in ss null mutants is unlike any normal appendage segment in that it completely lacks bristles or cuticular hairs. This segment is followed distally by most or all of a fifth tarsal segment terminated by claws. 


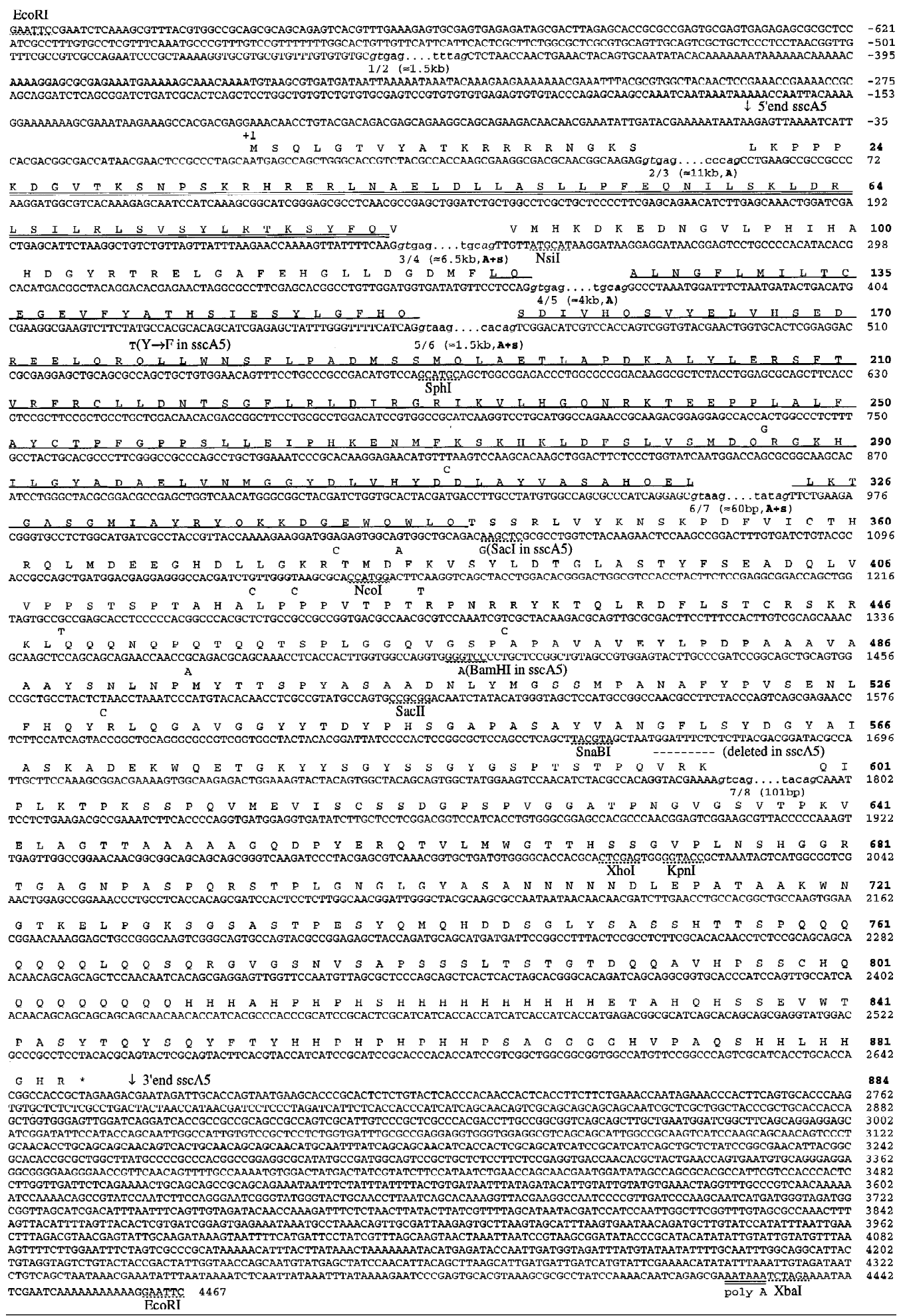

Figure 2. Sequence of the SS CDNAs. The sequence and conceptual translation of the SS CDNA SSCA6 is shown, along with the polymorphisms associated with the SsCA 5 CDNA. The nucleotide sequence is numbered by plain text at the end of each row; the corresponding amino acid sequence numbering is depicted in boldface type. Downward-pointing arrows indicate the ends of the sscA 5 cD N A; broken lines above nucleotides +1789 through +1797 indicate the three codons absent in the sscA 5 cDNA. The bHLH region is double underlined; the PAS domain is single underlined. The translation stop is noted by an asterisk. The positions of the seven exon splice junctions are in lowercase text; the donor and splice acceptors are italicized; the three flanking intronic nucleotides are in plain text. The approximate length of each intron is in parentheses, and those splice sites conserved in A hr or sim are noted by a bold A and s, respectively. 


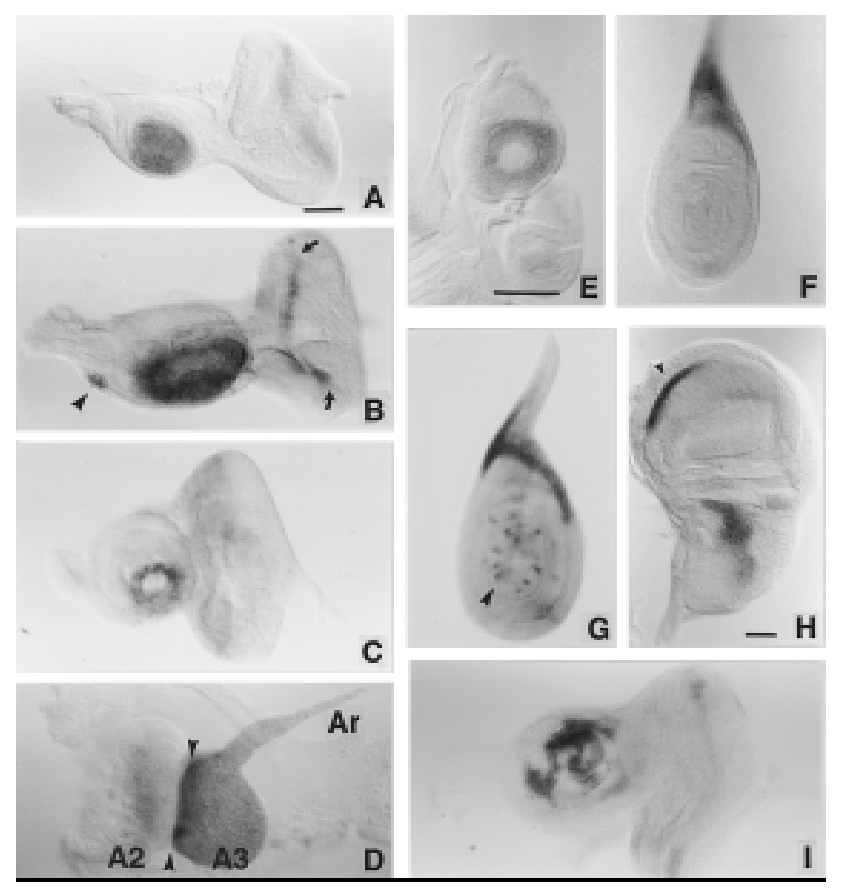

Figure 3. ss expression in imaginal discs. Imaginal discs from third instar larvae and pupae were hybridized with RN A probes transcribed from the XB3.2 genomic clone or the SSCA6 CDNA. $(A, B)$ Eye-antennal discs from early and late wild-type third instar larvae. In B the arrowhead indicates the maxillary palp anlage and the arrows indicate the morphogenetic furrow in the eye disc. (C) ss transcript accumulation in $\mathrm{Ss}^{\mathrm{a}}$ mutant (ss ${ }^{\mathrm{D} 114.3}$ / ss $^{\text {D114.4 }}$ ) third instar eye-antennal discs. The pattern resembles that in the wild-type early third instar leg (cf. E). (D) ss expression in an everted antennal disc. Arrowheads indicate the boundary between the second (A 2) and third (A 3) segments. (Ar) The arista. $(E-G)$ ss expression pattern in early $E$ and late $F$ third instar leg discs, and in a leg disc just prior to eversion (G). The arrowhead in $G$ indicates bristle precursor cell labeling. $(H)$ ss expression in a mature third instar wing disc. Expression is seen in an anteroventral stripe (arrowhead) and a patch in the presumptive notal region. (I) ss antennal expression in a heterozygote for the Antp gain-of-function allele Antp ${ }^{73 b}$. Variegated reduction in ss expression is seen. Scale bars, $50 \mu \mathrm{m}$; the bar in $A$ refers to $A-D$ and $I$; the bar in $E$ refers to $E, F$, and $G$.

Other adult structures In the late third instar, ss becomes expressed in a small patch in the antennal disc that corresponds to the maxillary palp anlage (Fig. 3B). Consistent with this, the maxillary palps of null mutants are truncated (Fig. 4F,G). This suggests a general requirement for ss in the development of distal structures in ventral appendages.

In the wing disc, ss is expressed in the presumptive notum and wing hinge region, and in a ventral stripe (Fig. $3 \mathrm{H})$. Perhaps related to this expression, the wings of null mutants are held perpendicular to the body and curve ventrally. The haltere disc stains in a similar pattern (not shown). Expression is also detected in the genital and labial discs (not shown), and in the morphogenetic furrow of the eye disc (Fig. 3B). Genital, labial, and eye development appear normal in ss mutants.
Bristle precursor cells At pupariation and disc eversion, stereotyped patterns of single large intensely stained cells are seen in most discs. This is shown only for the leg (Fig. 3G). The pattern of label ed cells is identical to that shown by the neuralized enhancer trap A101 (Huang et al. 1991), indi cating that these late ss expressing cells are sensory organ precursors. At later stages, intense staining is seen in developing bristle cells, but not in the associated socket cells.

Embryos As shown in Figure 5, ss is also expressed in embryos. ss staining first appears at stage 8 (all staging as in Campos-Ortega and Hartenstein 1985) in a crescent just anterior to the cephalic furrow. This staining develops rapidly into an intense patch. As germ-band extension continues, staining develops in the maxillary, labial, and mandibular segments, followed by expression in a ventral patch in all three thoracic segments. These patches were identified as the leg anl age by double-labeling for transcripts from ss and aristaless (Campbell et al. 1993; Schneitz et al. 1993) (not shown). ss staining al so appears in cells of the peripheral nervous system in each abdominal segment, as determined by double labeling for the A37 enhancer trap line (Ghysen and O'Kane 1989) (not shown). The ss staining pattern is maintained through germ-band retraction and continues until the deposition of Iarval cuticle makes it difficult to follow further.

To position the ss head patch, embryos were stained for both ss transcript and engrailed (en) protein. As can be seen in Figure 6 , the posterior boundary of the ss antennal patch coincides precisely with the posterior edge of the antennal en stripe. There is a one-to-one correspondence between ss- and en-expressing cells for some distance along this stripe, although the en antennal stripe extends ventrally several cell s beyond the ss patch. The anterior limit of ss expression lies just posterior to the en head spot, which delimits the posterior border of the ocular segment (Schmidt-Ott and Technau 1992). Thus, ss is expressed throughout most or all of the embryonic antennal segment, and is expressed in a segmental, not parasegmental, register.

The expression of ss in embryos was unexpected, as no embryonic defects have been described for ss mutants. However, examination of null mutant larvae revealed that the antennal sense organ is misshapen and often sclerotized (Fig. 4J). In addition, the dorso-medial papilla of the maxillary sense organ, which is thought to be derived from the antennal segment (Jürgens et al. 1986), fails to migrate completely (Fig. 4K). Examination of $\mathrm{Ss}^{-}$ embryos stained with the monoclonal antibody $22 \mathrm{C} 10$ (Zipursky et al. 1984) failed to reveal any defects in the peripheral nervous system.

\section{Ectopic expression of ss}

To assess the devel opmental potential of ss, we used the GAL4/UAS system (Brand and Perrimon 1993) to drive ectopic expression of the SsCA 5 CDNA. M ost GAL4 drivers tested proved to be lethal in combination with UAS- 
Figure 4. Cuticular phenotypes of ss mutants. The antennal and leg phenotypes of ss mutants have been described by others [see Lindsley and Zimm (1992) and references therein]. (A,B) Antennae from wild-type $(A)$ and $\mathrm{ss}^{\mathrm{a}}\left(\mathrm{ss}^{\mathrm{D} 114.10} / \mathrm{ss}^{\mathrm{D} 114.4}\right)(B)$ adults. The first (A1), second (A2), and third (A3) antennal segments and the arista (Ar) are indicated. The antennal tarsus in $\mathrm{ss}^{\mathrm{a}}$ mutants is judged to have T2 identity by the following criteria: Paired rows of stout bracted macrochaetae present ventrally (Hollingsworth 1964) are like those on the second leg; the most distal bristle pair in each segment is larger than more proximal pairs; on average, there are three pairs of bristles in the fifth tarsal segment (Lawrence et al. 1979); and there are no posterior transverse bristle rows in the second tarsal segment. (C) Antenna from a ss null mutant (ss $\left.{ }^{\mathrm{D} 115.7}\right)$. A3 has no bristles or trichomes, and most of the distal tarsal region is absent. (D-E) Distal second leg of wild-type and a ss null mutant. Tarsal segments 2-4 and part of segment 1 are deleted in E. (F,G) Wild-type and ss null mutant maxillary palps. The mutant
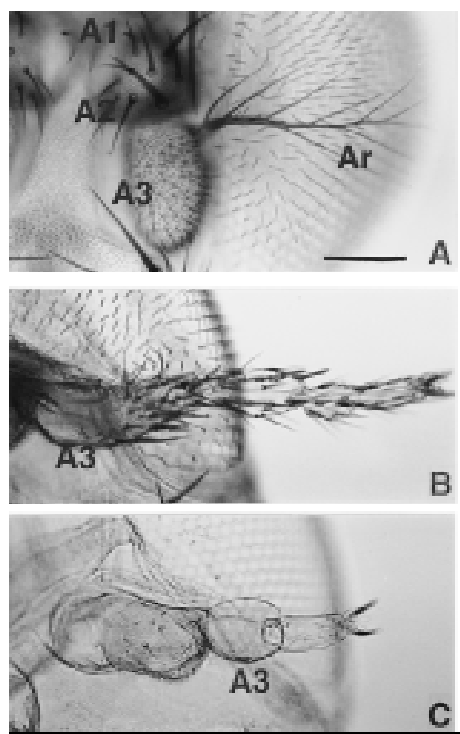

B

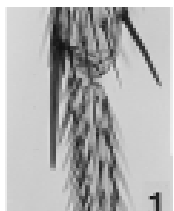

1
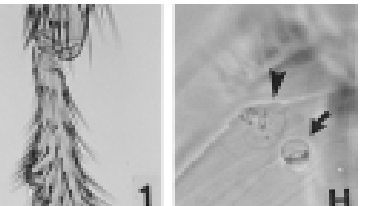

A

ull mutant (I,K) first instar antennal and maxillary sense organs (AnSO and $M \times S O$ ). The AnSO is indicated with a large arrow, the MxSO with a large arrowhead, and the dorsomedial papilla (DMP) with a small arrowhead. In the mutant the AnSO is cauliflower-shaped and has no clear stalk, and migration of the DMP is impaired. Scale bars, A-G (shown in A), $100 \mu \mathrm{m}$; H-K (shown in $\mathrm{H}$ ), $10 \mu \mathrm{m}$.

ss. Embryos from a cross to the 69B driver (Brand and Perrimon 1993), which is expressed in the embryonic ectoderm and its derivatives (Baylies et al. 1995), were examined in detail. These show a loss of midline structures, as well as tracheal system defects (Fig. 7l, J). These phenotypes are similar to those caused by mutations in the sim and trh genes, which encode PAS domain proteins. Ectopic ss likely interferes with the function of these proteins, perhaps by competition for a common dimerization partner.

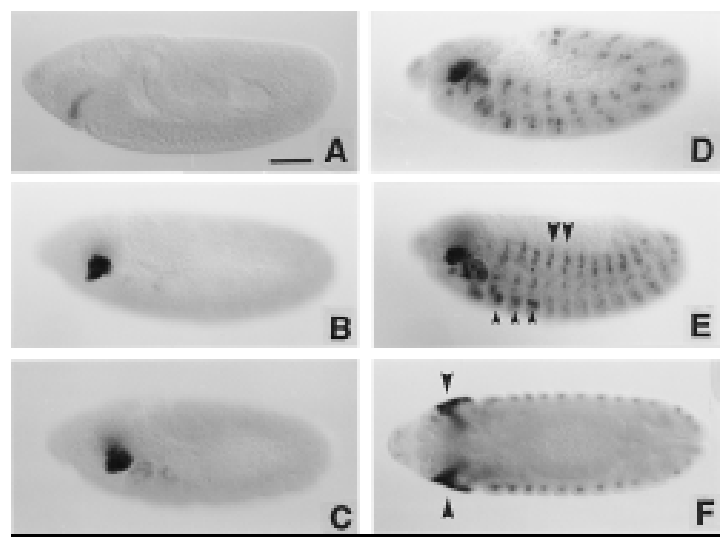

Figure 5. ss transcript distribution in embryos. (A- E) The pattern of ss transcript distribution beginning at stage 8 and continuing through late embryogenesis. Small arrowheads in E indicate the leg anlage; large arrowheads indicate expression in the peripheral nervous system. In F, an optical section midway through a germ-band retracted embryo shows the extent of expression in the invaginating eye-antennal discs (arrowheads). Scale bar, $50 \mu \mathrm{m}$.
A few driver/UAS-sS combinations survived to the pharate adult stage, al lowing us to determine the effects of ectopic ss on adult structures. The results indicate that ss is a primary determinant of distal antennal identity. The ptc-GAL4 driver (Hinz et al. 1994) has been

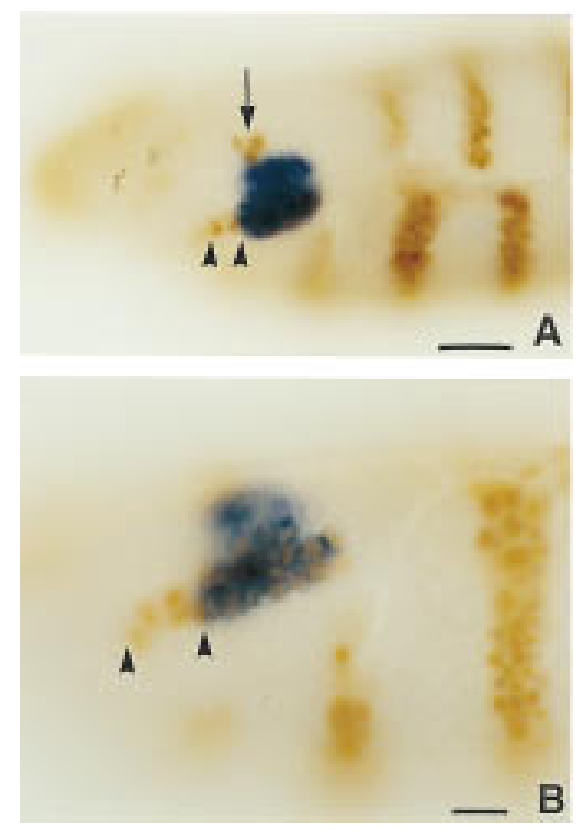

Figure 6. ss expression in the antennal segment of the embryo. $(A, B)$ Wild-type embryos double label ed for ss transcript (blue) and en protein (brown). N ote that the limits of ss expression extend from just ventral to the en head spot (arrow) through the antennal en stripe (arrowheads). The most ventral cells of the latter do not express ss. Scale bar in A, $20 \mu \mathrm{m}$; in B, $10 \mu \mathrm{m}$. 


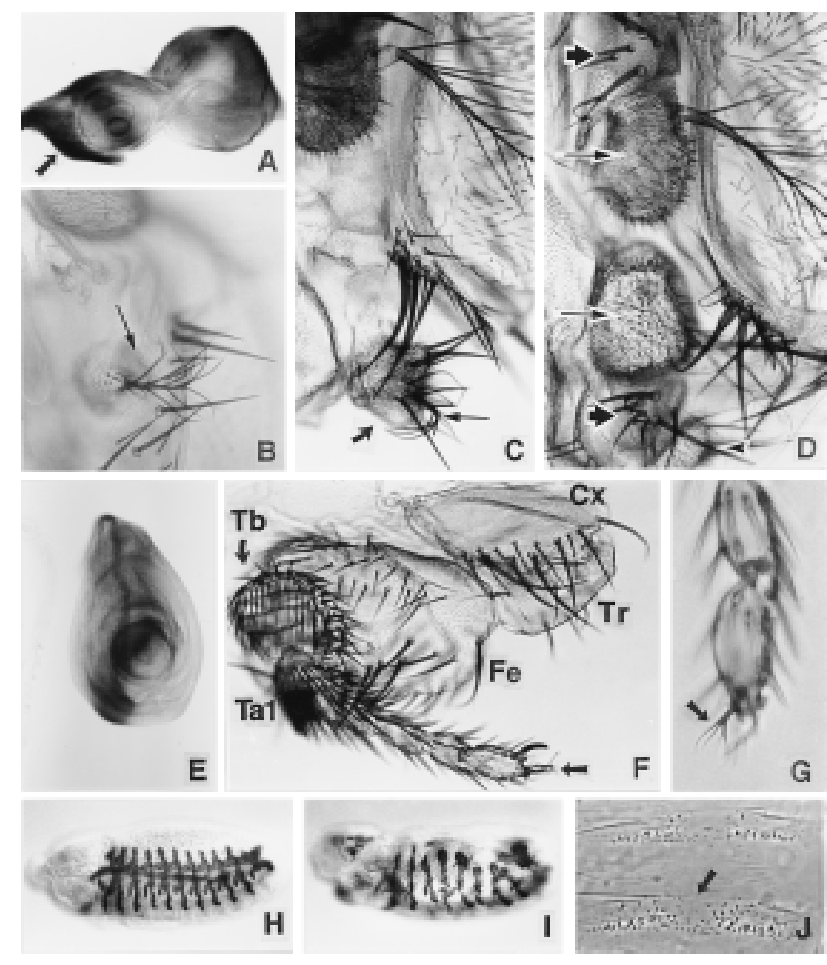

Figure 7. Effects of ss ectopic expression. (A) Pattern of ectopic expression driven by ptc-GAL4 in the eye-antennal disc ( $\beta$ gal actosi dase staining). The arrow indicates a zone of high-level ectopic expression that includes the primordia of the palp and rostral membrane. (B-D) The effects of ectopic expression of ss driven by ptc-GAL4 in the head. A partial ectopic antenna (arrow) that has developed in an out pocketing of the rostral membrane is shown in $B$, and partial transformation of the palp (thick arrow) to arista (thin arrow) and Alll is shown in C. In D, an almost complete ectopic antenna is present in the rostral membrane region. N ote that AllI (long arrows) and All (short arrows) in the normal and ectopic antennae are arranged mirror symmetrically. The palp (arrowhead) is still present. The arista of the ectopic antenna is out of the plane of focus. (E- G) The effects of ectopic ss in the leg. The pattern of ectopic expression driven in the leg disc by ptc-GAL4 is shown in E. Deletion of most of the femur (Fe) and tibia (Tb) is shown in $\mathrm{F}$. The coxa $(C X)$, trochanter (Tr), and most of the tarsus (Ta) are unaffected. Aristae are present at the distal tips of the legs shown in $\mathrm{F}$ and $\mathrm{G}$ (see arrows). ( $\mathrm{H}-\mathrm{J}$ ) Effects of ectopic ss in embryos. $\mathrm{H}$ shows a normal embryo stained for the trh enhancer trap 1-eve-1 (Wilk et al. 1996). Ectopic ss driven by the 69B GAL4 driver causes severe abnormalities in this pattern (I). Ectopic ss also causes the del etion of midline portions of the denticle belts (arrow in J), similar to the effects of sim mutants.

studied in most detail. It is expressed in imaginal discs at high level immediately anterior to the compartment boundary. ss expression driven by ptc-GAL4 causes transformation of the maxillary pal $p$, rostral membrane, and distal leg to antenna. Transformation of the palps varies from essentially no effect to an almost complete transformation to AIII and arista (Fig. 7C). Palps are also often deleted. Surprisingly, ectopic ss induces ectopic antennal structures in the rostral membrane between the palp and the normal antenna. These range from small patches of AIII and arista (Fig. 7B) to entire ectopic antennae (Fig. 7D), and are al ways arranged in mirror symmetry to the normal antenna. Ectopic ss expression al so causes transformation of the distal leg to arista (Fig. $7 F, G$ ). In some cases, aristal-claw intermediates are present, indicating that aristae can arise by transformation of claws. More proximal antennal structures are never present in the leg, and the pulvillus and tarsi are unaffected. Curiously, in most cases the basal cylinder of the arista is suppressed by ectopic ss.

The frequency of induction of ectopic antennae in the rostral membrane was $88 \%$ (67 hal f heads scored) in heterozygotes for ptc-GAL4 and our standard UAS-ss insertion (line A 1). In this same genotype, transformations of distal leg to arista occurred at a frequency of 66\% (100 legs scored). Because pal ps are usually absent in this genotype, the frequency of palp transformations was determined in flies carrying a weakly responding UAS-sS insertion (line C2). Of 100 palps scored, 27 carried an arista, and 15 showed wavy arista-like bristles.

Ectopic expression of ss also causes the deletion of medial leg structures. This occurs in $100 \%$ of ptc-GAL4; UAS-Ss legs. Anterior structures from the distal femur and most of the tibia are deleted (Fig. 7F). Much of what appears to be the posterior compartment remains, however, and produces irregular cuticular outgrowths. The distortion these cause makes it difficult to define precisely the limits of the deleted regions. The distal basitarsus is clearly retained, however, because sex combs are present in the first legs of males. More distal tarsal segments are usually unaffected, with the exception of transformation of claw to arista. ss expression driven by ptc-GAL4 also causes deletion of the central part of the wing, and induces a zone of polarity reversal in the abdominal tergites (not shown). A few scattered bristles are also induced in the wing blade. The significance of these effects is not known.

\section{Position of ss in the limb development hierarchy}

The DII gene is required for the development of all leg segments distal to the coxa (Cohen and Jürgens 1989; Gorfinkiel et al. 1997). To test whether ss lies downstream of DII in limb development, we examined ss expression in a weak DII loss-of-function mutant, DII ${ }^{\mathrm{PK}}$. This al lele survives to the pharate adult stage when heterozygous with DII null alleles such as DII ${ }^{\mathrm{B}}$, and causes the deletion of distal limb structures. We find that ss expression is almost completely eliminated in the tarsus, antenna, and maxillary palp of $\mathrm{DII} \mathrm{PK}^{\mathrm{PK}} / \mathrm{DII}{ }^{\mathrm{B}}$ heterozygotes (not shown). Thus, ss lies downstream of DII in all three of these appendages. In the antenna, ss expression is reduced in animals that carry only one dose of $\mathrm{DII}^{+}$ (not shown). This presumably accounts for the weak transformation of distal antenna to leg seen in most DII mutant heterozygotes (Sunkel and Whittle 1987).

To monitor DII expression in relation to ss, we (in collaboration with Dr. S. Cohen, EM BL, Heidel berg, Germany) isolated a monoclonal antibody against DII pro- 


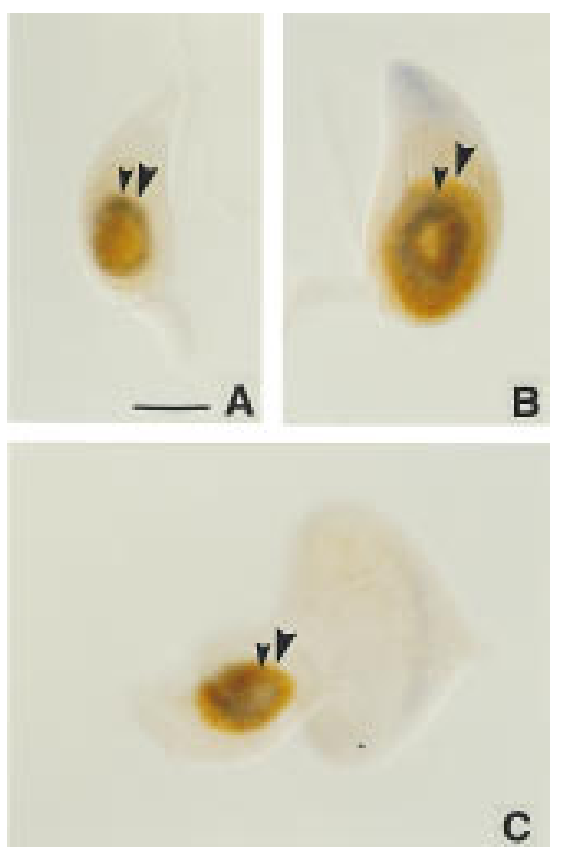

Figure 8. Wild-type imaginal discs double-labeled for ss transcript (blue) and DII protein (brown). Small arrowheads indicate the proximal extent of ss expression; large arrowheads indicate the proximal extent of DII expression. In early third instar leg $\operatorname{discs}(A)$, the proximal extents of ss and DII expression coincide; later discs show DII expression more proximal than Ss (B). In antennal discs, DII expression is always more proximal than ss (C). Scale bar, $50 \mu \mathrm{m}$.

tein. As shown in Figure 8, DII is expressed uniformly in the central portions of the leg and antennal imaginal discs. In the early third instar, when ss is first expressed in the leg, the outer edge of the ss tarsal ring coincides precisely with the proximal limit of DII expression. As the leg disc grows, the boundary of DII expression expands beyond the ss tarsal ring, so that a proximal zone of cells that express DII, but not ss, is created. In the antenna, DII expression extends more proximally than ss at all stages we have examined.

The transient early expression of ss in the leg suggests that ss plays a role in the establishment of the tarsal region. Support for such a role is provided by the finding that bab lies downstream of ss. In wild type, bab expression is initiated in the tarsal region in the mid-third instar, and at disc eversion bab expression can be seen to extend from the middle of the first tarsal segment through the fifth segment (Godt et al. 1993). In ss null mutants, bab expression is abolished in the leg (not shown).

\section{Discussion}

Homology to the mammalian dioxin receptor

ss is the closest known relative of the mammalian AHR, also known as the dioxin receptor (for review, see
Schmidt and Bradfield 1996). All five splice junctions within the coding region for the ss bHLH and PAS domains are conserved precisely in A hr, indicating that the ss and AHR proteins share common ancestry. The basic regions of the two proteins are identical at 10/13 residues, suggesting they bind similar or identical DNA sequences. AHR functions to activate the transcription of genes that are important in metabolizing polycyclic aromatic hydrocarbons. AHR is normally cytoplasmic, but on binding aryl hydrocarbons, it translocates to the nucleus and forms active heterodimers with another bHLH-PAS protein, the aryl hydrocarbon nuclear translocator. The ligand with the highest affinity known for AHR is dioxin. The similarity of ss to AHR suggests that ss protein might also bind some type of ligand. Despite their close similarity, ss and AHR appear to be unrelated in function. Ahr knockouts in the mouse show no obvious developmental defects (Fernandez-Salguero et al. 1995; Schmidt et al. 1996), although, as expected, they are unresponsive to aryl hydrocarbons.

\section{Control of antennal identity by ss}

In previous work, we tested a specific model for how ss might act indirectly to control distal antennal identity (Burgess and Duncan 1990). Because ectopic expression of the Antp gene can cause a distally complete transformation of antenna to second leg (Schneuwly et al. 1987), we suspected that the $s s^{\mathrm{a}}$ antennal transformation might result from the ectopic activation of Antp+. To test this, we examined $\mathrm{Antp}^{-} \mathrm{ss}^{\mathrm{a}}$ mitotic recombination cl ones in the distal antenna. To our surprise, we found these are indistinguishable from $\mathrm{Antp}^{+} \mathrm{Ss}^{\mathrm{a}}$ clones, and are transformed to second leg tarsus. This demonstrated that the $\mathrm{Ss}^{\mathrm{a}}$ antennal transformation is independent of $\mathrm{Antp}^{+}$, and led us to propose that $\mathrm{ss}^{+}$controls distal antennal identity directly. The molecular characterization of ss provides strong support for this proposal.

In normal development, ss is expressed in the primordia of Alll and the arista in the antennal imaginal disc. This corresponds to the portion of the antenna affected in ss null mutants. When ss is expressed ectopically, we find that it can transform the maxillary palp to AllI and arista, and the distal leg to arista. Ectopic ss al so induces formation of an ectopic antenna in the rostral membrane ventral to the normal antenna. These effects argue strongly that ss is an antennal determinant. However, only certain structures are suscepti ble to transformati on by ectopic Ss, suggesting that ss must interact with other spatially-restricted regulators to promote antennal identity.

Transformations of distal antenna to leg are caused by ectopic expression of a number of different genes, including Antp, Scr, U bx, abd-A, and Abd-B (Casares et al. 1996 and references therein) and the mouse genes $\mathrm{H}$ oxA 5 (Zhao et al. 1993) and HoxB6 (M al icki et al. 1990). Transformation of distal antenna to leg is also seen in Polycomb heterozygotes (Duncan and Lewis 1982) and in animals having only one dose of DII (Sunkel and Whittle 1987). These effects have led to the view that transfor- 
mations of the distal antenna to leg are somehow nonspecific. However, in all of these cases (except ectopic expression of Abd-B, which has not yet been tested) we find that distal antennal transformations are correlated with repression of ss in the antenna (Fig. 3I; D.M. Duncan and I.W. Duncan, unpubl.). Thus, rather than indicating any lack of specificity for the $\mathrm{ss}^{\mathrm{a}}$ transformation, these cases provide strong supporting evidence that ss is a primary determinant of distal antennal identity.

The induction of antennae in the rostral membrane by ectopic ss was quite unexpected. This region normally produces no appendage and does not express DII, which is thought to be required for ventral appendage formation (Cohen and Jürgens 1989). Moreover, the antennae induced here are often complete, al though ss is normally expressed only in AIII and the arista. It would appear that ectopic ss can initiate an entire antennal limb program in the rostral membrane. Consistent with this, we find that ectopic ss induces DII expression in this location (not shown). Ectopic antennae are always oriented in mirror symmetry to the normal antenna, suggesting that they arise from a cryptic head segment that is organized in mirror symmetry to the antennal segment. The existence of such a segment has al so been inferred by Gonzáles-C respo and M orata (1995).

\section{Establishment of the tarsal primordium}

Like the antenna, the second leg tarsus appears to de velop without input from the ANT-C and BX-C genes. $M$ itotic recombination clones homozygous for null alleles of the major homeotic genes expressed in the thorax (Scr, A ntp, and U bx) develop normally in the T2 tarsus (Struhl 1981, 1982b; Abbott and Kaufman 1986), although Antp ${ }^{-}$clones in more proximal regions of the T2 leg are transformed to antenna. Struhl (1981) suggested that the lack of effect of Antp ${ }^{-}$clones in the T 2 tarsus is caused by nonautonomous rescue by nearby wild-type cells in the adjacent compartment. However, our finding that $\mathrm{Antp}^{-} \mathrm{ss}^{\mathrm{a}}$ Clones in the distal antenna produce apparently normal T2 tarsi (Burgess and Duncan 1990) argues that $\mathrm{Antp}^{+}$simply plays no role in the second leg tarsus.

The results presented in this report suggest that the T 2 tarsus is specified by ss. ss is first expressed in the tarsal region in the late second instar. Staining increases in this region through the early third instar, and then gradually declines. As far as we are aware, ss is the only discpatterning gene known that shows such transient expression. Consistent with this expression pattern, the temperature-sensitive period of ss for tarsal development is in the first half of the third instar (M gl inets 1976). This period probably coincides with when the tarsal primordi um is establ ished, as Schubiger (1974) found that when leg discs are forced to undergo premature metamorphosis, the tarsal region first develops competence to differentiate in the early third instar. Significantly, Schubiger found that the tarsal regions differentiated by leg discs of this age are not segmented. Thus, it would appear that tarsal development occurs in two phases: First, a uniform tarsal region is established, and then this region is subdivided into special ized segments. We suggest that ss is responsi ble for the first of these phases, whereas downstream genes are responsible for the second. The timing of maximal ss expression, the temperature-sensitive period of ss, and the finding that ss expression is not segmentally modulated within the tarsal ring are all consistent with this view. Ectopic expression of ss in the leg causes the deletion of medial structures. Although it is not clear how these pattern deletions arise, one possibility is that ectopic ss specifies medial leg regions as tarsus, causing them to become incorporated into the tarsal primordium.

Our results indicate that ss occupies an intermediate position in the leg developmental hierarchy. Tarsal expression of ss is abolished in a DII loss-of-function mutant, indicating that DII is an important upstream regulator of ss. When ss first becomes expressed in the tarsal primordium, its proximal limit of expression coincides precisely with that of DII. This suggests that DII might di rectly activate ss in the leg, thereby defining its proximal limit of expression. DII also appears to be a positive regulator of ss in the antenna: ss expression here is reduced in animals having only one dose of $\mathrm{DII}^{+}$, and is almost eliminated in a DII loss-of-function mutant. In light of these observations, it is surprising that ectopic ss induces DII expression in the rostral membrane. Whether this reversal of the expected regulatory relationship between DII and ss has any rel evance to normal development is not clear, because DII expression appears to be unaffected in ss null mutants (not shown). We find that tarsal expressi on of bab, which is required for proper subdivision of the tarsus into segments (Godt et al. 1993), is abolished in ss null mutants, indicating that bab lies downstream of ss in leg development.

What determines whether ss specifies tarsal or antennal development?

At least in the antenna, the level of ss function appears to determine whether tarsal or distal antennal development is specified. The many ss alleles induced by chemical mutagens, which are likely to be mutations in the coding sequence, can be arranged in a phenotypic series in which weak alleles cause only transformations of arista to tarsus, whereas strong alleles al so cause tarsal deletions and a loss of AllI identity (Struhl 1982a). These observations suggest that a high level of ss function is required to specify aristal identity, whereas lower levels are able to specify tarsus and AllI identity. Consistent with this, we find that the intensity of ss staining is much higher in the antennal disc than in the leg disc. The level of function also appears to be critical for the proboscipedia $(\mathrm{pb})$ gene of the ANT-C: pb null alleles cause a transformation of proboscis to tarsus, weak activity of $\mathrm{pb}^{+}$causes a transformation to arista, and stronger activity allows normal proboscis development (Cribbs et al . 1995). Whether the tarsal and aristal trans- 
formations seen in pb mutants result from the activation of different levels of ss in the proboscis has not been determined.

It is perhaps surprising that when ss expression was driven ectopically in the leg, the tarsal segments were never transformed to antenna, although the distal tip was often transformed to arista. However, we find that the ptc-GAL4 driver used does not activate ss in the leg nearly as strongly as it does in the antennal disc. Thus, the level of ectopic expression attained in the tarsal region may not have been sufficient to cause a transformation. Alternatively, ectopi c ss may have no effect in tarsi because of the absence or presence of some critical cofactor in the leg.

The $\mathrm{ss}^{-}$antennal appendage may be close to an epigenetic ground state

The $\mathrm{ss}^{-}$antennal appendage develops in the absence of ANT-C and BX-C, as well as Ss, gene function, suggesting it is close to a developmental ground state. The prevailing view has been that the limb ground state is T 2 leg (e.g., see Struhl 1982b and references therein). However, this has been chal lenged by the finding that Antp- clones in the proximal second leg are transformed to antenna (Struhl 1981, 1982b; A bbott and Kaufman 1986), and the finding that all trunk body segments devel op antennae in Tribolium embryos deficient for the HOM-C (Stuart et al. 1991). A possible resolution was suggested by Struhl (1981, 1982b), who proposed that Antp ${ }^{+}$functions to preserve the T2 ground state by repressing putative headdetermining genes in the second leg. This model predicts that inactivation of these head-determining genes should cause the antenna to develop as second leg. The distal antennal transformation caused by weak $\mathrm{ss}^{\mathrm{a}}$ mutants would seem to conform to this prediction. However, in ss null mutants, Alll is not transformed to second leg, but develops as an undecorated segment with no apparent identity. We suggest that this is the fate of an appendage segment that has not been specified by any homeotic gene. As described in Figure 9, we propose that the limb ground state is a four-segmented appendage similar to the $\mathrm{ss}^{-}$antenna, and that $\mathrm{Ss}^{+}$and Antp ${ }^{+}$function to direct the special ization of this appendage to produce the antenna and second leg.

\section{Evolutionary speculations}

It is generally considered that the arthropod antenna evolved from a leg-like locomotory appendage (e.g., see Callahan 1979), a view that has received support from work on Drosophila homeotic and segmentation genes (Postlethwait and Schneiderman 1971; Cohen and Jürgens 1989; Schmidt-Ott and Technau 1992; this report). It is also generally accepted that unsegmented tarsi are ancestral in the hexapods (Boudreaux 1987), because simple tarsi resembling those present in ss mutant Drosophila occur in crustaceans and primitive hexapods. Thus, both the transformation of antenna to leg and the tarsal deletions caused by ss mutations appear to be ata-

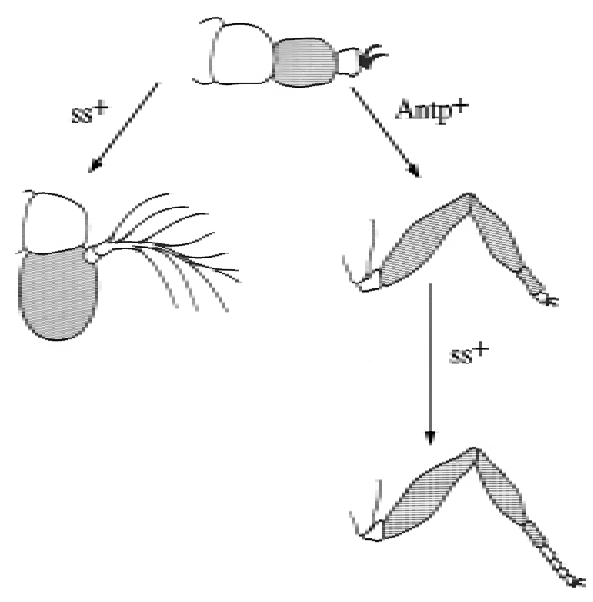

Figure 9. The $\mathrm{Ss}^{-}$antennal appendage is close to an epigenetic ground state. The antennal appendage in $\mathrm{ss}^{-}$animals is indicated schematically at the top. The third segment of this appendage and its derivatives in the antenna and leg are shaded to indicate homology. As indicated, $\mathrm{ss}^{+}$functions in the antenna to specialize the third and fourth segments of the ground state appendage to produce AIII and arista. In T2, Antp ${ }^{+}$specifies the identities of the proximal two segments of the ground state appendage as coxa and trochanter, and directs the third segment to expand and subsegment to produce the femur, tibia, and first tarsal segment. These functions of Antp are consistent with the phenotype of Antp ${ }^{-}$clones in the leg (Struhl 1981, 1982b; Abbott and Kaufman 1986), and with the effects of ectopic expression of Antp in the antenna (Postlethwait and Schneiderman 1971). In the distal leg, $\mathrm{ss}^{+}$directs the expansion and segmentation of the tarsus. The diagram predicts that the Antp ${ }^{-} \mathrm{Ss}^{-}$second leg will look like the ss $^{-}$antennal appendage. Although this has not yet been tested, the predicted phenotype is consistent with the additive effects of $\mathrm{Ss}^{-}$and Antp ${ }^{-}$single mutants. The proximal two segments of the indicated ground state appendage are normal antennal segments; presumably the identities of these are specified by some other, currently unknown, homeotic gene or genes. Whether the evolutionary ground state of the limb is the same as the devel opmental ground state is not clear. However, it seems reasonable to suggest that it may be, and that an ancestral four-segmented appendage similar to the $\mathrm{ss}^{-}$antenna became specialized in the head to produce the antenna, and in the thorax to produce legs.

vistic, suggesting that ss played an important role in the evolution of distal limb structures in the arthropods.

Because antennal special ization occurred very early in arthropod evolution, we think it likely that the first function of ss was antennal specification, and that ss was recruited into tarsal development much later, during the evolution of the hexapods. Antennae are often elongated appendages used for probing the environment, and we think it plausible that as part of antennal specification, ss came to have an appendage el ongation function. Transient expression of this function could then have served to extend other limbs, including the legs. This evol utionary sequence predicts that ss homologs will prove to be expressed in the antenna, but not the legs, of crustaceans and primitive hexapods, but in both locations in the insects. 


\section{Materials and methods}

Screen for new ss alleles

Isogenic $\mathrm{ss}^{+}$males (either from Canton-S or a st $\mathrm{p}^{\mathrm{p}}$ line) were irradiated (4000 rads of $X$ rays) and crossed to $\mathrm{sbd}^{2} \mathrm{ss}^{\mathrm{aM} 204} / \mathrm{TM} 1$ females. N on-TM 1 progeny were then screened for the $\mathrm{Ss}^{\mathrm{a}}$ antennal transformation. $\mathrm{SS}^{\mathrm{aM} 204}$ is a weak ss allele kindly provided by Dr. Ernesto Sánchez-Herrero (Universidad Autónoma de M adrid, Madrid, Spain). It shows a good antennal transformation, but little or no bristle or leg effects, when heterozygous with ss null alleles.

\section{Cloning}

Cloning, Southern blotting, and restriction mapping were by standard procedures (Sambrook et al. 1989). In situ hybridization to polytene chromosomes was as described by Cai et al. (1994). Previously described mutations mapped in this report include $\mathrm{Tp}(3 ; 2) \mathrm{P} 10, \mathrm{In}(3 \mathrm{LR}) \mathrm{P} 88, \mathrm{~T}(1 ; 3) \mathrm{Ss}^{\mathrm{v}}$, and $\mathrm{T}(2 ; 3) \mathrm{Ss}^{\mathrm{a} 75}$ (Lindsley and Zimm 1992); Tp(1;3)sta (M elnick et al. 1993); and Df(3R)RS3-32 (Hopmann et al. 1995).

\section{In situ hybridizations}

Digoxigenin-labeled RN A probes were used in a modification of the method of Tautz and Pfeifle (1989) (R. Blackman, pers. comm.). After staining, samples were dehydrated through an ethanol series and mounted in $80 \%$ Permount (Fisher scientific) : $20 \%$ methyl salicylate or wet mounted in $50 \%$ glycerol in 50 $\mathrm{mm}$ Tris at pH 8.8. Double in situ/antibody staining was essentially as described by Manoukian and Krause (1992).

\section{CDNA analysis}

SS CDN A clones were isolated from a $\lambda$ gt10 eye/ antennal imaginal disc library kindly provided by G. Rubin. CDNAs corresponding to the centrally located $1.2-\mathrm{kb}$ transcript were obtained from an adult $\lambda$ Exlox library (N ovagen). Clones were sequenced in entirety on both strands from single-stranded DNA by use of the Sequenase kit (U.S. Biochemical).

\section{Antibody staining}

With the exception of imaginal discs, tissue staining was essentially as described by Kellerman et al. (1990). Imaginal discs were found to give unacceptable background when streptavidinbased reagents were used, presumably because of the presence of endogenous biotin. Therefore, prior to incubation with bi otinylated secondary anti bodi es, discs were blocked by a 20-min treatment with unlabeled streptavidin $(0.5 \mu \mathrm{g} / \mathrm{ml}$ in PBS) followed by a $20-\mathrm{min}$ treatment with biotin $(20 \mu \mathrm{g} / \mathrm{ml}$ in PBS). Tissues were dehydrated, mounted, and photographed as for the in situ samples. The anti-en hybridoma 4D9 (Patel et al. 1989) was obtained from the American Type Culture Collection.

\section{Monoclonal anti-DII antibody}

Balb/c mice were immunized with bacterially expressed DII protein and shipped to us by Dr. Stephen Cohen. Spleen cells were fused to Sp2/0 myeloma cells, and supernates of clones surviving HAT sel ection were screened by staining of 6- to 18-hr embryos. Clones showing positive responses were expanded and used for the production of ascites stocks. The antibody used in this analysis, MAb DMDII.1, stains imaginal discs well, but stains embryos relatively poorly. The antibody is of isotype IgG2b.
Larval and adult cuticle preparations

Larvae were mounted in a mixture of $38 \%$ Shandon Immumount, $52 \%$ saturated chloral hydrate in water, and $10 \%$ lactic acid syrup. Processing of adult tissues was as described in Duncan (1982).

\section{Sequence analysis}

All sequence analysis was performed by use of the Wisconsin Genetics Computer Group sequence analysis software (Devereux et al. 1984) on a Vaxstation 3100 computer. Genbank databases were searched by the BLAST program (Altschul et al. 1990). The sequence of the sscA6 cDNA has been deposited with GenBank under accession number AF050630.

\section{Acknowledgments}

We thank Gerard Campbell, Shigeo Hayashi, Frank Laski, Martha O'Brien, Norbert Perrimon, Jim Posakony, and Ernesto Sánchez-Herrero for providing stocks; Konrad Basler, Nick Brown, Tom Kornberg, and Gerry Rubin for cDNA libraries; Ron Blackman for an in situ hybridization protocol; Markus $\mathrm{N}$ oll for the al CDN A, and Paul Taghert for the 22C10 monoclonal. Steve Cohen provided DII-immunized mice, and Mark Sturtevant constructed several of the plasmid subclones used. We are especially grateful to Paula Kiefel and Elaine Round for help in sequencing splice junctions and Richard Emmons for isolating UAS-ss transformants. Finally, we thank Mark Kankel, Richard Emmons, Artyom Kopp, and the anonymous reviewers for comments on the manuscript.

The publication costs of this article were defrayed in part by payment of page charges. This article must therefore be hereby marked "advertisement" in accordance with 18 USC section 1734 solely to indicate this fact.

\section{References}

Abbot, M.K. and T.C. Kaufman. 1986. The relationship between the functional complexity and the molecular organization of the Antennapedia locus of Drosophila melanogaster. Genetics 114: 919-942.

Altschul, S.F., W. Gish, W. Miller, E.W. Myers, and D.J. Lipman. 1990. Basic local alignment search tool. J. Mol. Biol. 215: 403-410.

Baylies, M.K., A. Martinez Arias, and M. Bate. 1995. wingless is required for the formation of a subset of muscle founder cells during Drosophila embryogenesis. Development 121: 38293837.

Boudreaux, H.B. 1987. Arthropod Phylogeny, with special reference to insects. Robert E. Krieger Publishing, M al abar, FL.

Brand, A. and N. Perrimon. 1993. Targeted gene expression as a means of altering cell fates and generating dominant phenotypes. Development 118: 401-415.

Bryant, P.J. 1978. Pattern formation in imaginal discs. In The genetics and biology of Drosophila, Vol. 2c (ed. M. Ashburner and T.R.F. Wright), pp. 230-335. Academic Press, $\mathrm{N}$ ew York, NY.

Burgess, E.A. and I. Duncan. 1990. Direct control of antennal identity by the spineless-aristapedia gene of Drosophila. Mol. \& Gen. Genet. 221: 347-352.

Cai, H., P. Kiefel, J. Yee, and I. Duncan. 1994. A yeast artificial chromosome clone map of the Drosophila genome. Genetics 136: 1385-1401.

Callahan, P.S. 1979. Evolution of antennae, their sensilla and the mechanism of scent detection in Arthropoda. In Arthro- 
pod phylogeny (ed. A.P. Gupta), pp 259-298. Van N ostrand Reinhold Co, N ew York, NY.

Campbell, G., T. Weaver, and A. Tomlinson. 1993. Axis specification in the devel oping Drosophila appendage: the role of wingless, decapentaplegic, and the homeobox gene aristaless. Cell 74: 1113-1123.

Campos-Ortega, J.A. and V. Hartenstein 1985. The embryonic development of Drosophila melanogaster. Springer-Verlag, Berlin, Germany.

Carroll, S.B., S.D. Weatherbee, and J.A. Langeland. 1995. Homeotic genes and the regulation and evolution of insect wing number. Nature 375: 58-61.

Casares, F., M. Calleja, and E. Sánchez-Herrero. 1996. Functional similarity in appendage specification by the UItrabithorax and abdominal-A Drosophila HOX genes. EMBO J. 15: 3934-3942.

Cavener, D.R. 1987. Comparison of the consensus sequence flanking translational start sites in Drosophila and vertebrates. Nucleic Acids Res. 15: 1353-1361.

Cohen, S.M. and G. Jürgens. 1989. Proximal-distal pattern formation in Drosophila: Cell autonomous requirement for Distal-less gene activity in limb development. EMBO J. 8: 2045-2055.

Cribbs, D.L., C. Benassayag, F.M . Randazzo, and T.C. Kaufman. 1995. Levels of homeotic protein function can determine developmental identity: Evidence from low-level expression of the Drosophila homeotic gene proboscipedia under $\mathrm{Hsp} 70$ control. EMBO J. 14: 767-778.

Cumberledge, S., A. Zaratzian, and S. Sakonju. 1990. Characterization of two RN As transcribed from the cis-regulatory re gion of the abd-A domain within the Drosophila bithorax complex. Proc. Natl. Acad. Sci. 87: 3259-3263.

DevereuX, J., P. Haeberli, and O. Smithies. 1984. A comprehensive set of sequence analysis programs for the VAX. Nucleic Acids Res. 12: 387-395.

Duncan, I.M. 1982. Polycomblike: A gene that appears to be required for the normal expression of the bithorax and Antennapedia gene complexes of Drosophila mel anogaster. Genetics 102: 49-70.

Duncan, I. 1987. The bithorax complex. Annu. Rev. Genet. 21: 285-319.

Duncan, I.M. and E.B. Lewis. 1982. Genetic control of body segment differentiation in Drosophila. In Devel opmental order: Its origin and regulation, the 40th symposium of the Society for Developmental Biology (ed. S. Subtelny and P.B. Green), pp. 533-554. Alan Liss, N ew York, NY.

Fernandez-Salguero, P., T. Pineau, D.M. Hilbert, T. McPhail, S.S.T. Lee, S. Kimura, D.W. N ebert, S. Rudikoff, J.M. Ward, and F.J. Gonzalez. 1995. Immune system impairment and hepatic fibrosis in mice lacking the dioxin-binding A $h$ receptor. Science 268: 722-726.

Ghysen, A. and C. O'Kane. 1989. Neural enhancer-like elements as specific cell markers in Drosophila. Development 105: 35-52.

Godt, D., J.-L. Couderc, S.E. Cramton, and F.A. Laski. 1993. Pattern formation in the limbs of Drosophila: bric à brac is expressed in both a gradient and a wave-like pattern and is required for specification and proper segmentation of the tarsus. Development 119: 799-812.

González-Crespo, S. and G. Morata. 1995. Control of Drosophila adult pattern by extradenticle. Development 121: 2117-2125.

Gorfinkiel, N., G. M orata, and I. Guerrero. 1997. The homeobox gene Distal-less induces ventral appendage development in Drosophila. Genes \& Dev. 11: 2259-2271.

Hinz, U., B. Giebel, and J.A. Campos-Ortega. 1994. The basic- helix-loop-helix domain of Drosophila lethal of scute protein is sufficient for proneural function and activates neurogenic genes. Cell 76: 77-87.

Hollingsworth, M.J. 1964. Sex-combs of intersexes and the arrangement of the chaetae on the legs of Drosophila. J. Morphol. 115: 35-52.

Hopmann, R., D. Duncan, and I. Duncan. 1995. Transvection in the iab-5,6,7 region of the bithorax complex of Drosophila: Homology independent interactions in trans. Genetics 139: 815-833.

Huang, F., C. Dambly-Chaudiere, and A. Ghysen. 1991. The emergence of sense organs in the wing disc of Drosophila. Development 111: 1087-1095.

Huang, Z.J., I. Edery, and M. Rosbash. 1993. PAS is a dimerization domain common to Drosophila Period and several transcription factors. Nature 364: 259-262.

Jürgens, G. and V. Hartenstein. 1993. The terminal regions of the body pattern. In The development of Drosophila melanogaster (ed. M. Bate and A. Martinez Arias), pp. 687-746. Cold Spring Harbor Laboratory Press, Cold Spring Harbor, NY.

Jürgens, G., R. Lehmann, M. Schardin, and C. N üsslein-Volhard. 1986. Segmental organisation of the head in the embryo of Drosophila melanogaster. Wilhelm Roux's Arch. Dev. Biol. 195: 359-377.

Kaufman, T.C., M.A. Seeger, and G. Olsen. 1990. M olecular and genetic organization of the Antennapedia Gene Complex of Drosophila melanogaster. Adv. Genet. 27: 309-362.

Kellerman, K.A., D.M. Mattson, and I. Duncan. 1990. Mutations affecting the stability of the fushi tarazu protein of Drosophila. Genes \& Dev. 4: 1936-1950.

Kim, J., A. Sebring, J.J. Esch, M .E. Kraus, K. Vorwerk, J. M agee, and S.B. Carroll. 1996. Integration of positional signals and regulation of wing formation and identity by Drosophila vestigial gene. Nature 382: 133-138.

Lawrence, P.A., G. Struhl, and G. M orata. 1979. Bristle patterns and compartment boundaries in the tarsi of Drosophila. J. Embryol. Exp. Morphol. 51: 195-208.

Lewis, E.B. 1963. Genes and developmental pathways. Am. Zool. 3: 33-56.

-_- 1978. A gene complex controlling segmentation in Drosophila. Nature 276: 565-570.

Lindsley, D.L. and G.G. Zimm. 1992. The Genome of Drosophila melanogaster. Academic Press, San Diego, CA.

Lipshitz, H.D., D.A. Peattie, and D.S. Hogness. 1987. Novel transcripts from the UItrabithorax domain of the bithorax complex. Genes \& Dev. 1: 307-322.

Malicki, J., K. Schugart, and W. M cGinnis. 1990. M ouse Hox-2.2 specifies thoracic segmental identity in Drosophila embryos and larvae. Cell 63: 961-967.

Manoukian, A.S. and H.M. Krause. 1992. Concentration-dependent activities of the even-skipped protein in Drosophila embryos. Genes \& Dev. 6: 1740-1751.

Melnick, M.B., E. N oll, and N. Perrimon. 1993. The Drosophila stubarista phenotype is associated with a dosage effect of the putative ribosome-associated protein D-p40 on spineless. Genetics 135: 553-564.

Mglinets, V.A. 1976. Time of gene action in the ontogenesis of Drosophila. Temperature-sensitive period of the $\mathrm{ss}^{\mathrm{a} 40 \mathrm{a}} \mathrm{mu}-$ tation in Drosophila melanogaster. O ntogenez 7: 192-196.

Morata, G. and P.A. Lawrence. 1979. Development of the eyeantenna imaginal disc of Drosophila. Dev. Biol. 70: 355-371.

Patel, N.H., E. Martin-Blanco, K.G. Coleman, S.J. Poole, M.C. Ellis, T.B. Kornberg, and C.S. Goodman. 1989. Expression of engrailed proteins in arthropods, annelids, and chordates. Cell 58: 955-968. 
Postl ethwait, J.H. and H.A. Schneiderman. 1971. Pattern formation and determination in the antenna of the homoeotic mutant Antennapedia of Drosophila melanogaster. Dev. Biol. 25: 606-640.

Raff, R.A. and T.C. Kaufman. 1983. Embryos, genes, and evoIution. Macmillan Publishing, N ew York, NY.

Sambrook, J., E.F. Fritsch, and T. Maniatis. 1989. Molecular cloning: A laboratory manual, 2nd ed. Cold Spring Harbor Laboratory Press, Cold Spring Harbor, NY.

Schmidt, J.V. and C.A. Bradfield. 1996. Ah receptor signaling pathways. Annu. Rev. Cell Dev. Biol. 12: 55-89.

Schmidt, J.V., L.A. Carver, and C.A. Bradfield. 1993. Molecular characterization of the murine Ahr gene. J. Biol. Chem. 268: 22203-22209.

Schmidt, J.V., G.H.-T. Su, J.K. Reddy, M.C. Simon, and C.A. Bradfield. 1996. Characterization of a murine Ahr allele: Animal model for the toxicity of halogenated dioxins and biphenyls. Proc. Natl. Acad. Sci. 93: 6731-6736.

Schmidt-Ott, U. and G.M. Technau. 1992. Expression of en and wg in the embryonic head and brain of Drosophila indicates a refolded band of seven segment remnants. Development 116: 111-125.

Schneitz, K., P. Spielmann, and M. Noll. 1993. Molecular genetics of aristaless, a prd-type homeo box gene involved in the morphogenesis of proximal and distal pattern elements in a subset of appendages in Drosophila. Genes \& Dev. 7: 114-129.

Schneuwly, S., R. Klemenz, and W.J. Gehring. 1987. Redesigning the body plan of Drosophila by ectopic expression of the homeotic gene Antennapedia. Nature 325: 816-818.

Schubiger, G. 1974. Acquisition of differentiative competence in the imaginal leg discs of Drosophila. Wilhelm Roux' Arch. 174: 303-311.

Struhl, G. 1981. A homoeotic mutation transforming leg to antenna in Drosophila. Nature 292: 635-638.

_- - 1982a. spinel ess-aristapedia: A homeotic gene that does not control the development of specific compartments in Drosophila. Genetics 102: 737-749.

- - . 1982b. Genes controlling segmental specification in the Drosophila thorax. Proc. Natl. Acad. Sci. 79: 7380-7384.

Stuart, J.J., S.J. Brown, R.W. Beeman, and R.E. Denell. 1991. A deficiency of the homeotic complex of the beetle Tribolium. Nature 350: 72-74.

Sunkel, C.E. and J.R.S. Whittle. 1987. Brista: A gene involved in the specification and differentiation of distal cephalic and thoracic structures in Drosophila melanogaster. Wilhelm Roux's Arch. Dev. Biol. 196: 124-132.

Tautz, D. and C. Pfeifle. 1989. A non-radioactive in situ hybridization method for the localization of specific RN As in Drosophila embryos reveals translational control of the segmentation gene hunchback. Chromosoma 98: 81-85.

Tian, H., S.L. McKnight, and D.W. Russell. 1997. Endothelial PAS domain protein 1 (EPAS1), a transcription factor selectively expressed in endothelial cells. Genes \& Dev. 11: 72-82.

Wilk, R., I. Weizman, and B.-Z. Shilo. 1996. trachealess encodes a bHLH-PAS protein that is an inducer of tracheal cell fates in Drosophila. Genes \& Dev. 10: 93-102.

Williams, J.A., J.B. Bell, and S.B. Carroll. 1991. Control of Drosophila wing and hal tere development by the nuclear vestigial gene product. Genes \& Dev. 5: 2481-2495.

Zhao, J.J., R.A. Lazzarini, and L. Pick. 1993. The mouse Hox-1.3 gene is functionally equival ent to the Drosophila Sex combs reduced gene. Genes \& Dev. 7: 343-354.

Zipursky, S.L., T.R. Venkatesh, D.B. Teplow, and S. Benzer. 1984. Neuronal development in the Drosophila retina: Monoclonal antibodies as molecular probes. Cell 36: 15-26. 


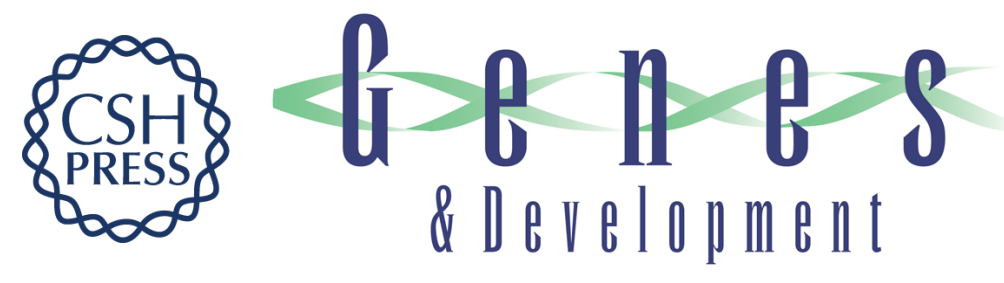

\section{Control of distal antennal identity and tarsal development in Drosophila by spineless-aristapedia, a homolog of the mammalian dioxin receptor}

Dianne M. Duncan, Elizabeth A. Burgess and lan Duncan

Genes Dev. 1998, 12:

References This article cites 57 articles, 27 of which can be accessed free at:

http://genesdev.cshlp.org/content/12/9/1290.full.html\#ref-list-1

License

Email Alerting Receive free email alerts when new articles cite this article - sign up in the box at the top Service right corner of the article or click here.

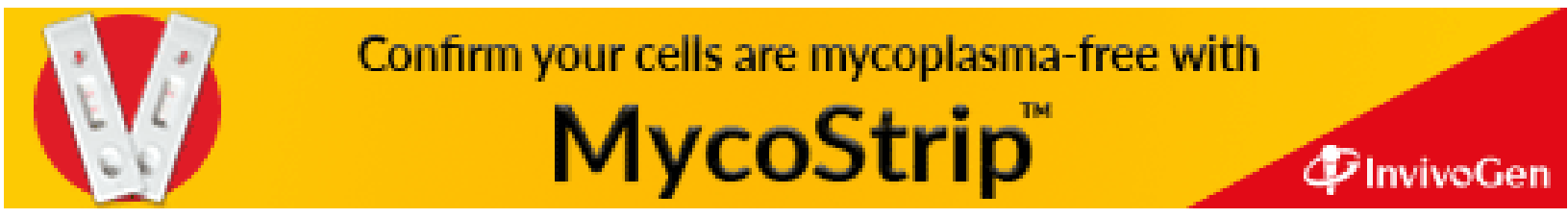

